\title{
Ideology of Sayyid Qutb and Movement of Tarbiyah in Indonesia: A Linguistics Approach
}

\author{
Zamzam Nurhuda \\ Indonesian Departement, Faculty of Letters, Pamulang University \\ Pamulang, Indonesia. \\ Syarif Hidayatullah State Islamic University Jakarta, Indonesia \\ e-mail: izam_albukhori@yahoo.co.id
}

\begin{abstract}
This study aims at revealing that one's ideology can be interpreted through his actualization of language. Furthermore, this study is qualitative, applying library research. Therefore, steps done in composing this study are collecting the data, clarifying the data, analyzing the data, accomplishing the conclusion and making a report. It also applies linguistics and psychology approaches. In linguistics studies, psychology relates to the internal concept of language (ideology). In other words, it is focused on language as a notion and an abstract area, known as ideas. The ideas become a source to actualize language in a form of sound (phonology). The primary data in this study are language facts found in works of Sayyid Qutb, such as Tafsir fi Zilal al-Qur'an, Ma'alim fi al-Thariq (1979), Ma'rakatuna Ma' alYahud (1993), and al-'Adalah al-Ijtima'iyah fi al-Islam (1995). The result of this study is ideology of Sayyid Qutb as interpreted from his language performance is an Islamic fundamental key. His language performance is tendentious, as depicted in his concepts of Harakah Difa 'iyah and Harakah Indifa', al-Nizam alTasyri'i and Nizam Fasid, Qiyadah Syar'iyah and Qiyadah Jahiliyah, al-Hakimiyah al-'Ulya' and al-Hakimiyah al-Basyar, alJahiliyah al-Hadithah and al-Jahiliyah al-Ula',Hizb Allah and Hizb al-Syaitan. Besides, half of Qutb's concepts are materials agenda of Tarbiyah.
\end{abstract}

Keywords- Sayyid Qutb; Ideology in Language; Movement of Tarbiyah; Fundamentalist Islam.

\section{INTRODUCTION}

Basically, ideology distinctions are characteristics of numerous historical-social and cultural social. As pointed by Faisal Darraj a study of ideology occurs as the effect of differences in pursuing illogical understanding that leads to various kinds of interpretation. This interpretation may relate to dissimilarities in social situation and condition, religion, vision and mission, individual or groups' interests. It may also due to alienation from certain social background, religion conflicts, even rejection toward religion and habit differences from a particular principle [5].

Meanwhile, Haedar Nasir defines ideology based on Arabic language. He assumes that most of Islamic people know Arabic word al-mabda' as translated to ideology. Almabda' means a basic thought followed by a further thought. Al-mabda' is also described as a basic thought to place other related thoughts [11]. Furthermore, ideology can be interpreted through language. Bambi B. Schieffelin and San Diego Kathryn portray ideology and language as a representation of culture in implicit and explicit modes, based on an understanding toward language and human beings in social life. Then, through mediation between social structure and speech form, ideology is actualized with language. In this case, languages function to connect ideology as identity, strengths, aesthetics, morality, and epistemology. Through this connection, ideology and language does not only support each other in forms of linguistics and linguistic practice but also in significant social institutions [20].

Ruth Wodak differentiates various aspects of ideology potency and politic of language in numerous contexts and sexual categories. It simply put that all languages are ideological or each language used to deliver ideology goals or politic ideas are totally incorrect. It is because language is as powerful as weapons which are able to terribly explode [21].

J. Trevor Morley in his study focusing on exploring the connection between languages, states about a concept of ideology and power in linguistic practice of contemporary society through Critical Discourse Analysis. This critical discourse analysis is fundamental to apply other linguistic approaches on exploring and describing a social basic of ideological dimension and power that support discourse in society [9].

Andreu Bauza Sastre tries to depict the significance between language planning and ideological politics. $\mathrm{He}$ exposes some beginnings definition about a concept of language planning and ideological politics. Then, he discusses its potential connection and several popular figures who have ideas on this concept relating to its role in the doctrine of nationalism. Hence, this study reveals how political influences with different ideology in Catalan area become the main factor in implementation of different language planning processes [19].

According to A Jacqueline H. E. Messing, for an outsider, ambivalence is a central ideology of teenagers' languages correlating with their identity, but this ideology takes a role in creating language's changes from times to times. Moreover, a further concern needs to come to those teenagers engaging with their language social practice and the role of language ideology movement on an individual. This is a key to revitalize languages because if ideological orientation can change from times to times, these teenagers may activate their passive linguistic knowledge [8].

Furthermore, language and ideology has a strong relation with religion. As stated by Komarudin Hidayat, the relation between religion as a tool and an expression of religiosity is as complex as human's dynamic minds, feelings, 
and activities. Besides the connection between language and ideology as mentioned by the previous experts, there are other Islamic experts describe ideology which is interpreted into language [6]. Haedar Nasir states that Islamic ideology is one of the latest improvements, called Islamism or Islamiyah. Sayyid Qutb through his fundamental ideology is one of those who inspire many Moslems to do enlightenment and jihad movements [11].

In most of his works, Qutb arouse religious strengths. The more Islamic organizations deliver their Islamic ideas, the more variations of languages can be found. Therefore, Islam is known as a religion which has numerous Islamic vocabulary. In this case, the development of ideological languages is influenced by one's or groups' surrounding. Those previous ideas explained actually have relevant ideas with this study. They highlight differences and similarities between other studies with this study [10].

\section{METHODS}

This study is qualitative, applying library research and analytic descriptive method. It attempts to resolve current matters. Then, techniques used in this study are collecting the data (as quoted in al-jahiliyah al-hadithah, hizb al-syaitan, harakah difa'iyah as a language that represents ideology of Sayyid Qutb), classifying the data (as quoted in al-Jahiliyah al-hadithah is classified as a contrary idea of al-jahiliyah alula', statement of hizb al-Syaitan is contrast with hizb Allah, harakah difa 'iyah is opposite of Harakah Indifa'), analyzing the data (as analyzed in a statement of al-jahiliyah alhadithah means jahiliyah that cannot be recognized clearly and it is more dangerous compared with the old jahiliyah), accomplishing the conclusion and making a report. Through those tecniques, it is expected to give a comprehensive and clear description on object of the study [12].

This study applied linguistics and psychology approaches. In linguistics studies, psychology relates to the internal concept of language (ideology). In other words, it is focused on language as a notion and an abstract area, known as ideas. The ideas become a source to actualize language in a form of sound (phonology). Meanwhile, the primary data in this study is languages found in works of Sayyid Qutb, such as Tafsir fi Zilal al-Qur'an, Ma'alim fi al-Tariq (1979), Ma'rakatuna Ma'al-Yahud (1993), and al-'Adalah alIjtima iyah fi al-Islam (1995).

\section{RESULT AND DISCUSSION}

The correlation between ideology and Sayyid Qutb's language indicates numerous values through his works. The write concluded these values as follows:

\section{A. Harakah Difa 'iyah, Harakah Indifa ‘}

As stated in QS. al-Baqarah: 190.

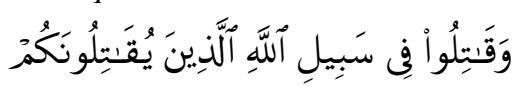

Qutb regards jihad as an action to realize systems of Allah in running life (jihad fi sabilillah) [14]. In his perspective, this jihad is a necessary movement, known as tawajuh al-harakah al-islamiyah, functions to replace all parts in secular system or al-anzhamah al-jahiliyah and it is impossible to face this secular system by surviving only, but it is more important to strengthen Islamic system in this world through tawajuh bi al-quwwah wa al-jihad [15]. Therefore, a holy jihad that is in the way of Allah is needed, bi wajib aljihad al-muqaddas fi sabilillah [16]. Furthermore, taking a part in a war requires to not only survive or al-harb difa iyah but also to do more. This survival may refer to those who are oppressed (al-mahjum) by current contemporary phenomenon (al-mustasyrikin al-makir). Qutb states that jihad focusing on surviving should be changed to more oppressive action or harakah indifa' [17].

\section{B. al-Nizam al-Tasyri', Nizam Fasid}

As stated in QS. al-Ma'idah: 47.

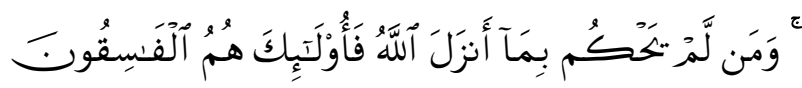

According to Qutb, those who do not make a decision for a lawsuit based on verses of Allah are kafir, zalim, and fasik (infidel, despotic, and wicked). In other words, they choose jahiliyah law and it is haram for Moslem to run jahiliyah conventions [17]. Thus, Qutb argues that Islamic system must be in Islamic corridors. The first corridor, all of conventions in religions from Allah requires to apply for rules of law must be based on Allah's verses. The second corridor, syariah in Islam must be upheld. The third corridor, Islamic syariah must be prioritized and syariah made by humans must be omitted [16]. This idea is portrayed in QS. alMai'dah: 50.

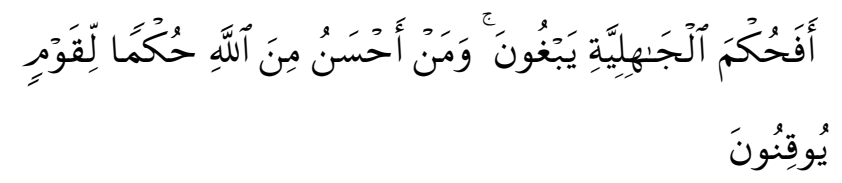

Qutb highlights that priotitizing syariah made by Allah must not be in the same scale in priotitizing syariah made by humans [16]. Those who regard human syariah is to be applied most are catagorized as kufur. That is what Qutb called nizam fasid [14].

\section{Qiyadah Syar iyah, Qiyadah Jahiliyah \\ As depicted in QS. al-'Araf: 3.}

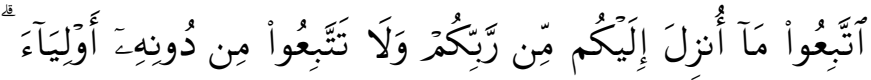

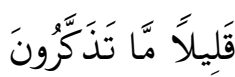

The verse above reveals that leaders, who bring to digression, as stated by Qutb, must not be obeyed. Besides, their role must be replaced by other leaders who follow rules created by Allah so that Moslems will run their life and follow rububiyah for Allah, the only one who owns everything and needs to be obeyed. Obeying another leader instead of Allah is identified as musyrik action because it implies as a rejection toward concepts of rububiyah purposed to then only one, Allah [17]. 
D. al-Hakimiyah al- 'Ulya', al-Hakimiyah al-Basyar

Qutb proposes an idea that hakimiyah is completly own by Allah. Power of Allah covers all phenomena of life so that Allah must be a guide for each people or al-sultan 'ala waqi'iyah al-hayah. In fact, there is no power which is stronger than Allah's and one's power is only temporary/alsulthan kulluh lillah [15]. Thus, this temporary world power (al-sultan al-ard) should be substitued with obedience for Allah or tard al-sultan al-tawaghit al-mughtasibin lisultan allah [17]. Yusuf: 40.

The concept of this sovereignty is depicted in QS

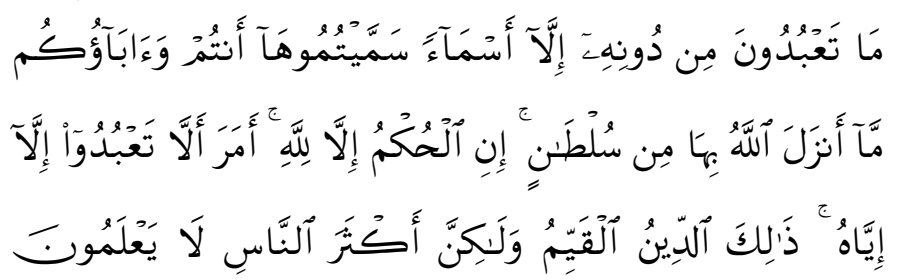

Qutb points out that this sovereignty means that there is no principles except those come from Allah or la hakimiyah illa minallah. The sovereignty of Allah is the most golorious one, it cannot be compared with other al-hakimiyah al- 'ulya'. Hence, Islamic people should be guided to understand and to obey sovereignty of Allah because it is the only way to take people to happiness in the world and the hereafter. Qutb called this phenomenon as al-hakimiyat lighairillah yarfud [15].

E. al-Jahiliyah al-Hadithah, al-Jahiliyah al-Ula'

In QS. al-Ahzab: 33, Qutb reveals about jahiliyah:

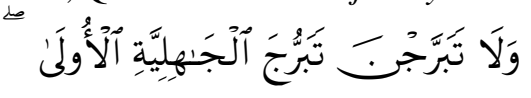

Through the verse above, Qutb proposed an idea that one of jahiliyah is called Jahiliyah al-ula' or jahilayah in Old Era. In this era, jahiliyah was regarded as the darkest civilization. Qutb called this era as jahiliyah since there were numerous jahiliyah actions/ nasya'it al-jahiliyahy occured. After there was an emergence of Islam, this nasa'it aljahiliyah was slowly replaced by Islamic systems (nizam alislam). These change and replacement occurred for lessons which were delivered by Prophet Muhammad, as a messenger of Allah for Arabic society in that era. However, this jahiliyah has been reborn in different ways, systems, and condition. The writer thinks that there is a different form of jahiliyah because in this era, there is jahiliyah, called jahiliyah al-majazi. It refers to jahiliyah which people do not seem to do wrong things even though they are totally wrong or hadhih aljahiliyah bi al-lughah al-islam. Qutb terms it as modern jahiliyah (al-jahiliyah al-jadidah, al-jahiliyah al-hadirah dan al-jahiliyah al-hadithah) [17].

\section{F. Hizb Allah, Hizb al-Syaitan}

As stated in QS. al-Syura: 7.

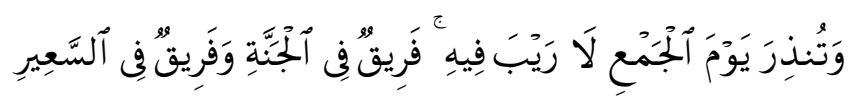

The verse implies that people are categorized into two when they are in the hereafter, those who go to heaven (hizb allah) and those who go to hell (hizb al-syaitan). Besides, in those two categories, there are other small groups. The groups consist of noble people are included to those go to heaven. On the other hand, the small groups consist of people who belong to hell will be reproached by Allah, The Al Mighty. Related to this idea, people are categorized into those who ignore Allah (kafir) and those who have faith to Allah the Al Mighty [13]. The best people of Allah are those who have faith and they are called fi sabilillah [17]. As written in QS. al-Imran: 110.

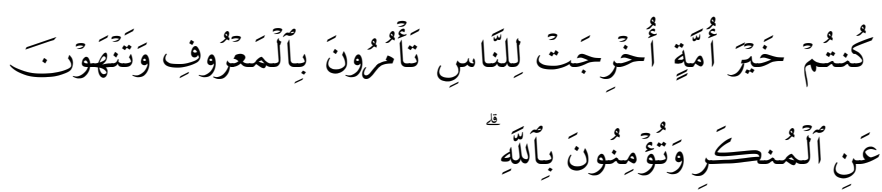

Through the verse, Qutb argues that the catefory of people who have faith to Allah can be realized by erasing all of non-Islamic principles.

$F$, Tarbiyah as an Islamic Movement Holding Relevance with Qutb's Ideology

The decade of 20th century was a benchmark for Middle East to witness a resurrection of Islamic militan influenced by Ikhwanul Muslimin. In this era, there occured vibrant activism and exclusivism salafi in resurrection of Islam. This ideology has an idea to oust the government and to replace it with Islamic state [3]. As an Egyptian, Qutb is accused as the most important pioneer in Islamic movement, called jihad. Works of Qutb when he was in prison (1950s and 1960s) were references for numerous Islamic movements and inspiration to run these movements [2]. Qutb's ideas, called as his competences in linguistics, become references for many Islamic groups. Then, Qutb's strong ideology drives leaders of these groups to deliver Islamic concepts through jihad [1]. Thus, Tarbiyah can be classified as a movement influenced by Qutb.

Tarbiyah movement is a transmission phase done by Ikhwanul Muslimin to Indonesia; it is marked through translating Ikhwanul Muslimin figures' books done by alumni of Middle East schools. One of the translated books is ma 'alim fi al-Tariq (Petunjuk Jalan) written by Sayyid Qutb. This fact indicates that the works of Qutb are used in Tarbiyah movement [4]. Petunjuk Jalan is a translated book of Qutb published by Media Dakwah. This publisher was owned by DDII in 1980s. For Tarbiyah movement and Campus' Dakwah movement, Petunjuk Jalan becomes the main book to be read. Consequently, this book takes a role in forming the basic character, material and manhaj for Tarbiyah movement in schools [18]. It also reveals that the target-reader of Media Dakwah is students and middle class people [7]. Besides, they are active to publish books which are harakah [4].

Furthermore, Abu Ridho via Imdadun Rahmat has generally quoted Qutb's ideas engaging with examples of 
Prophet Muhammad's noble lesson. This noble lesson was used to influence people as a dakwah's target, especially the target in siyasah context. Abu Ridho also takes an idea of Qutb about several phases passed in dakwah in order to establish Islamic systems and to destroy jahiliyah systems. First, Prophet Muhammad asked each Moslem to form a group which has commitment in obeying Allah and they have a willingness not to be a part of Jahiliyah society. Second, hijrah (in more general definition) should be done; hijrah means leaving behind Jahiliyah concepts and creating a true Islamic life. Third, Rasulullah Saw. created an Islamic state in Medina. This phase is also called Islamic brotherhood consolidation. Fourth, Prophet Muhammad did expansion around the world. According to Qutb, as revealed by Abu Ridho via Imdadun Rahmat, people of Islam need to apply this four phases in order to form a strong Moslem society in this current era [18].

Menwhile, in a side of state and government systems, an idea of Abu A'la al-Maududi that is also a primary concept of Qutb are used. Basically, many Tarbiyah millitan apply this concept. The main core of this figures' ideas are based on alQur'an and al-Sunnah, as the main souce of Islamic lesson. Thus, al-Qur'an and al-Sunnah have to be an ideology for a state and its governmental systems, such as in law and constitution. It also implies that a state should be controlled to importances of Islam [18]. This is actually one of Tarbiyah's agenda, which is, creating daulah Islamiyah, full of noble politicians who have faith to Allah. As a result, dakwah movement indirectly evolves to political movement [22].

Besides, Qutb's concepts revealed in his works have influenced the material concepts of Tarbiyah [4]. One of the concepts relate to hizb Allah and hizb al-Syaitan. In material agenda of Tarbiyah, it gives a material about Satan and their efforts to mislead human beings. It is also to identify those efforts which are probably found in Satan's adherents. Then, it is to understand the impacts of being a part of Satan's verses and to try to stay away from them [22]. After that, it is to understand Satan's bad influences (khutuwat al-syaitan), such as creating anxiety (waswasah) and forgetfullness (insa'), lenthening imagination (tanmiyah), making promises ( $w a^{\prime} d$ ), deceiving (kaid), misleading ways to Allah (sad) and estblihing hostility ('adawah). Meanwhile, hizb Allah delivers an idea that people of Allah have to confront those involving with hizb al-Syaitan. People of Hizb Allah have to believe that they are able to defeat hizb al-Syaitan and it is a statement of Allah [22].

Furthermore, Qutb's concepts become material in jahiliyah concepts. For tarbiyah, it is to learn how jahiliyah occurs and grow in human beings, both personally and communally. The goal of this material is to recognize jahiliyah actions as stated in al-Qur'an and how to anticipate to do these actions. An attempt to reveal jahiliyah in this era relates to prejudice of jahiliyah (zann al-jahiliyah), principal of jahiliyah (hukm al-jahiliyah), prays to serve jahiliyah (ibadah al-jahiliyah), proud of jahiliyah (hamiyah aljahiliyah), tradition of jahiliyah (taqalid jahiliyah) [22].

\section{CONCLUSIONS}

The result of this study shows that one's ideology can be interpreted through his his language actualization. In this study, it reveals that Sayyid Qutb' ideology can be interpreted through his language performances which are a fundamental of Islamic key. Besides, it is also disclosed Sayyid Qutb's performances is tendentious, such as concepts about (Harakah Difa 'iyah and Harakah Indifa), (al-Nizam al-Tasyri' $i$ and Nizam Fasid), (Qiyadah Syar'iyah and Qiyadah Jahiliyah),(al-Hakimiyah al-'Ulya' and alHakimiyah al-Basyar), (al-Jahiliyah al-Hadithah and alJahiliyah al-Ula'), and (Hizb Allah and Hizb al-Syaitan). Some of the concepts of Qutb belong to Tarbiyah material agenda. In agenda of Tarbiyah material, Qutb's concepts such as harakah, hizb, jahiliyah, etc becomes one of the main materials to deliver his idea. Therefore, Tarbiyah movement is Islamic movement influenced Qutb. Related to this idea, the functions of this study cover: First, to understand that language in one's way of thinking is a basic hing to form ideology. Second, one's ideology can be transformed into language. Third, Sayyid Qutb's language becomes a main reference for fundamental Islamic. Hence, through his ideology and language, Sayyid Qutb can be called as father of fundamental Islamic.

\section{ACKNOWLEDGMENT}

A bunch of thanks is delivered to many people who spiritually and materially supported the writer to conduct this study. A Special resfect to those that directly took a part in this study. First, to Unpam that financially helped the writer in the process of conducting and in publishing this study. Second, to LPPM Unpam that contributed in motivating the writer to be a productive educator. Third, to the committee International Conference on Culture and Language in Southeast Asia (ICCLAS) UIN Syarif Hidayatullah Jakarta that have geratly facilitated and helped so that this study deserve to be published.

\section{REFERENCES}

[1] Baskara, Nando. (2009). Gerilyawan-gerilyawan Militan Islam: dari al-Qaeda, Hizbullah, Hingga Hamas. Yogyakarta: Narasi.

[2] Brandon, James. (2009). Unlocking al-Qaeda: Islamist Extremism in British Prison. Quilliam.

[3] Bunzel, Cole. (2015). From Paper State to Caliphate: The Ideology of the Islamic State" The Brookings Project on U.S. Relations with the Islamic World.

[4] Damanik, Ali Said. (2016). Fenomena Partai Keadailan: Transformasi 20 Tahun Gerakan Tarbiyah Di Indonesia. Noura Books.

[5] Darraj, Faisal. (2010). al-Idiyulujiyah wa al-Ikhtilaf al-Idiyulujiyah. 'Amman: al-Nadwah al-Musytarikah bain al-Ma'had al-Mulkiy al-Dirasat al-Diniyah wa Muntada al-Fikri al-'Arabi.

[6] Hidayat, Komarudin. (2003). Memahami Bahasa Agama: Sebuah Kajian Hermeneutika. Bandung: Mizan Media Utama. 
[7] Luth, Thohir. (1999). M. Natsir, Dakwah dan Pemikirannya. Jakarta: Gema Insani Press.

[8] Messing, A Jacqueline H. E. (2009). Ambivalence and Ideology Among Mexicano Youth in Tlaxcala, Mexico. University of South Florida: Journal of Language, Identity \& Education, Taylor and France Group: 350-364.

[9] Morley, J. Trevor. (2004). Power And Ideology In Everyday Discourse: The Relevance Of Critical Discourse Analysis In Pragmatic Linguistics Today. Seminar of English Linguistics: 20-25.

[10] Nadia, Zunly. (2012). Akar-Akar Radikalisme Islam Dalam Tafsir Fi Dilal Al-Quran Karya Sayyid Qutb. Jurnal Studi Islam 18, No. 22: 301-323.

[11] Nashir, Haedar. (2014). Memahami Ideologi Muhammadiyah. Yogyakarta: Suara Muhammadiyah.

[12] Nurhuda, Zamzam. (2012). Bilngualisme dan Pengaruhnya Terhadap Bahasa Nasional: Studi Kasus Di Tarbiyah PKS. Jakarta: Ngudi Ilmu.

[13] Qardawi, Yusuf. (1999). Berinteraksi dengan alQuran. Penerjemah Abdul Hayyie al-Kattani. Jakarta: Gema Insani Press.

[14] Qutb, Sayyid. (1995). al-'Adalah al-Ijtima'iyyah fi al-Islam. Bairut: Dar al-Syuruk.

[15] Qutb, Sayyid. (1979). Ma'alim Fi al-Tariq. Bairut: Dar al-Syuruk.

[16] Qutb, Sayyid. (1993). Ma 'rakatuna' ma'a al-Yahud. Bairut: Dar al-Syuruk.

[17] Qutb, Sayyid. Fi Zilal al-Qur'an: Juz 1-30. Makkiyah: al-Tauhid wa al-Jihad.

[18] Rahmat, M. Imdadun.(2008). Ideologi Politik PKS dari Mesjid Kampus ke Gedung Parlemen. Yogyakarta: LKiS Yogyakarta.

[19] Sastre, Andreu Bauzà. (2000). Language Planning And Political Ideology: A Crosscomparison Between Catalonia, Valencia And The Balearic Islands On The Reintroduction Of Catalan. A Dissertation University Of Southampton, Faculty Of Arts Sc.

[20] Schieffelin, Bambi and B. San Diego Kathryn A. Woolar. (1998). Language Ideologies: Practice and Theory. Oxford University Press: USA.

[21] Wodak, Ruth. (2007). Language and Ideology Language in Ideology. Lancaster University: Journal of language and Poilitics, John Benjamin Publishing Company: 1-5.

[22] Yasmin, Ummu. 2009. Agenda Materi Tarbiyah: Panduan Kurikulum Dai dan Murabbi. Solo: Media Insani Press. 